\title{
Evaluation of the Properties of Cement Pastes and Mortars Used in the Encapsulation of Bituminized Waste
}

\author{
Vanessa Mota Vieira*, Clédola Cássia Oliveira de Tello \\ Department of Radioactive Waste, Nuclear Technology Development Center (CDTN / CNEN), Brazil
}

Copyright $\subset 2017$ by authors, all rights reserved. Authors agree that this article remains permanently open access under the terms of the Creative Commons Attribution License 4.0 International License

\begin{abstract}
The Brazilian repository is being planned to be a near-surface one. In Brazil the low and intermediate level radioactive wastes are immobilized using cement and bitumen for Angra 1 and Angra 2 NPP, respectively. The major problems due to the disposal of bituminized wastes in repositories are swelling of the waste products and their degradation in the long term. To accommodate the swelling of the bituminized wastes, the drums are filled up to $70-90 \%$ of their volume, which reduces the structural repository stability and the disposal availability. Countries, which use bitumen in the solidification of NPP's radioactive waste and have near-surface repositories, need to immobilize this bituminized waste within other drums containing cement pastes or mortars to dispose them. This study aims to evaluate the properties of cement pastes and mortars to be used in the encapsulation of bituminized wastes. The formulations of two pastes and two mortars were selected for the pilot scale tests. The laboratory and pilot scales results were very similar, indicating that any of these formulations could be used. However the better formulation will be chosen after the leaching test results, because it is an essential parameter in the long-term repository performance.
\end{abstract}

Keywords Radioactive Wastes, Bitumen, Cement Pastes, Mortars

\section{Introduction}

In Brazil, there are currently two nuclear power plants with PWR type in operation, located in Itaorna, Rio de Janeiro: Angra 1, Angra 2 and Angra 3 under construction. Angra 1 has the capacity to generate $640 \mathrm{MW}$ and Angra 2, $1350 \mathrm{MW}$. Angra 3 is expected to generate $1405 \mathrm{MW}$ [1].

In the Brazilian Nuclear Program, it was predicted that construction of, at least, four nuclear power plants in the Northeast and Southeast regions of Brazil, until 2030, to meet the increasing use of nuclear power to generate electricity $[1,2]$. With this growth and the increase of the use of radionuclides in different areas, the issue of radioactive waste deserves government actions that are been taken to resolve issues related to their storage [3].

Brazilian Federal Law 10.308 regulates the final destination of the radioactive waste produced in the country, including site selection, construction, licensing, operation, supervision, costs, damages, liability and warranties relating to deposits radioactive waste. The responsibility of CNEN for the final destination of the waste is established in the Article 2. In accordance of this regulation, it is not allowed to receive radioactive waste in liquid or gaseous forms in final repositories [4]. Therefore the solidification of waste is required in order to meet three basic criteria to ensure safe handling of radioactive waste in repositories, which are mechanical resistance, permeability and stability. The matrices used are cement, polymers, glass and bitumen [5].

The immobilization and solidification of radioactive waste of low and intermediate level radiation from Angra 1 and Angra 2 are carried out in cement and bitumen respectively. The most common method of final disposition (disposal) of this type of waste is its confinement in near surface repositories (Figure 1) [1].

Experiences of bituminized waste disposal on surface repository were reported in countries like Romania, where ion exchange resins are encapsulated in bitumen in 60 liter drums, which are then packed in $200 \mathrm{~L}$ drums with an intermediate concrete shielding.

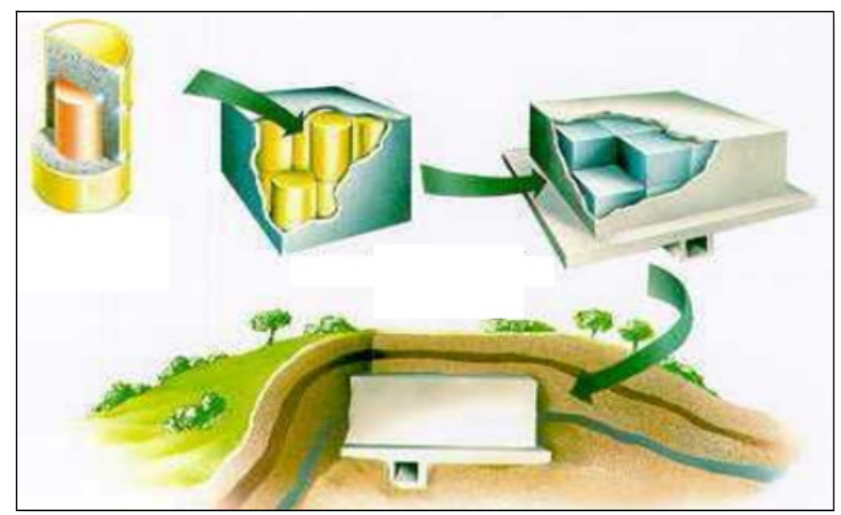


Figure 1. Near surface repository

Slovakia radioactive waste are incorporated into bitumen and this mixture is stored in $200 \mathrm{~L}$ drums coated with zinc (galvanizing), deposited in containers and transported to the surface Mochovce repository. In Czech Republic, 100L waste drums are encapsulated by high strength concrete in 200L drums, plates and galvanized corrosion-resistant paint, and then sent to the repository Dukovany [2]. Other countries such as France and Belgium have opted for bituminized waste disposal on Deep geological repository, minimizing the risks associated with these wastes [3].

There are also major problems due to the presence of bituminization products in repositories, which are swelling of the product and wasting long term degradation caused by fissures, softening by temperature variations, creeping because of its viscoplastic material, attacked by micro-organisms and, under certain conditions, fire hazard. To accommodate swelling, the drum must be filled in the range of $70-90 \%$ of its volume, which can decrease the structural stability of the repository and increase the necessary disposal of this area [4].

The implementation of the national repository is an important technical requirement and currently a legal requirement for the entry into operation of the plant Angra 3 [5].

This study aims to look for solutions to dispose the bituminized waste products in the repository, making them compatible with the acceptance criteria of cemented waste products.

\section{Material and Methods}

According to international experience, it will be using bitumen encapsulated in cement (paste or mortar). It was followed a $2^{3}$ factorial design with replicate to prepare the experimental work. The quantity of plasticizer and clay (bentonite) used was equivalent from $0.6 \%$ to $5 \%$ by weight of cement, respectively.

\subsection{Determination of Viscosity}

Viscosity is one of the properties in the cement paste which is a measure of the workability and determines the ease and homogeneity of which materials may be mixed, thus guaranteeing the best solidified products. The optimum viscosity will depend on the mixing system used by the nuclear power plant [6].

\subsection{Determination of Setting Time}

It is the moment from which the water present in the waste comes into contact with the cement, and begins the chemical reactions, whose consequence is gradual solidification. In practice, the setting time is an indication of compatibility between the waste and cement. It is an important property during the processing of waste, as it must be ensured that there is no solidification before the mixture was completely homogenized and it becomes a solid after the processing in order to be handled, stored and transported [7].

\subsection{Determination of Compressive Strength}

This test consists of subjecting the sample to the growing tension, continuing until its deformation or break, it is one of the most important mechanical characteristics. It is related to the degree of compression and the stiffness of the product. Therefore, products that are less minimum porous and more homogeneous, cracks and fissures tend to present more resistance to compression (Figure 2). The product must be resistant to impacts that may occur, especially during handling and transport [8].
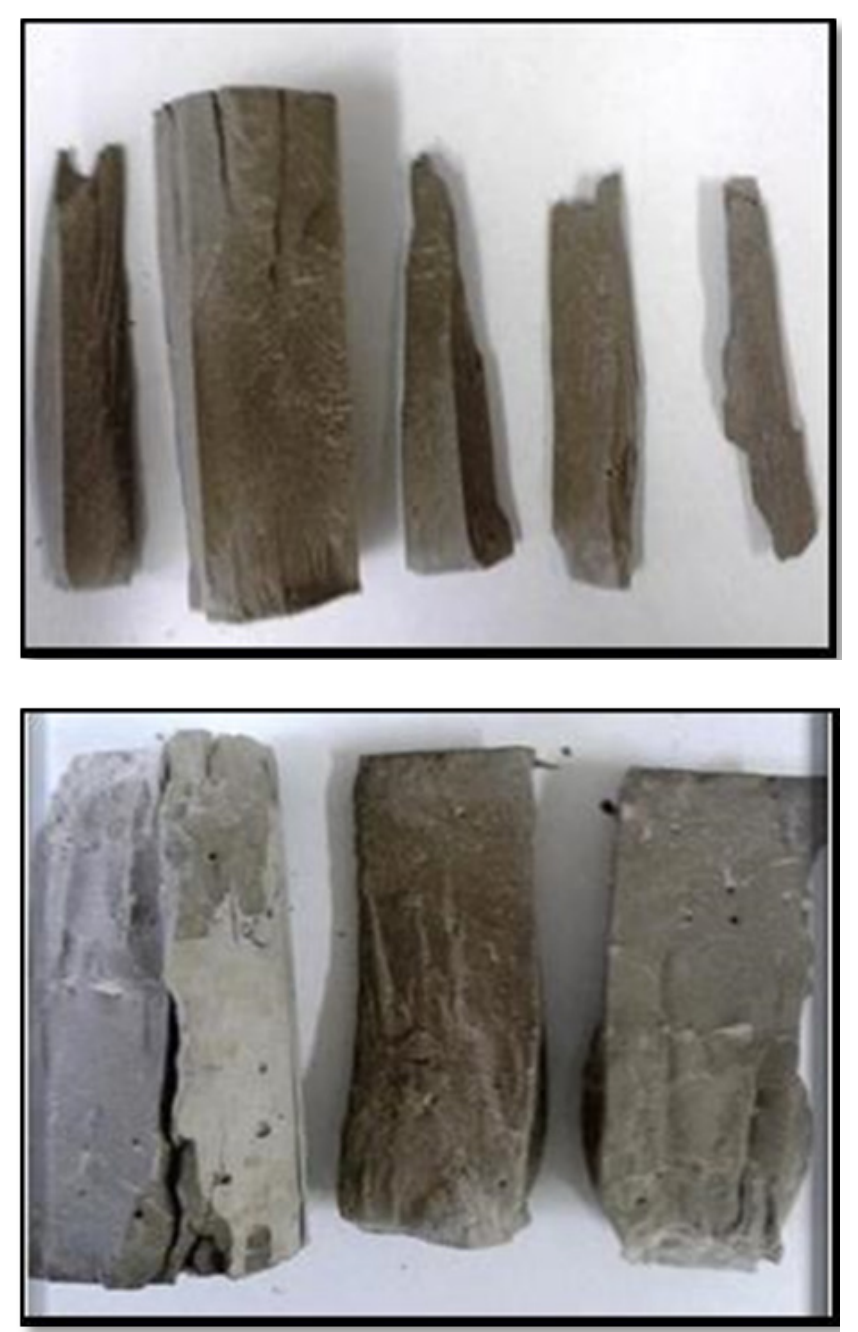

Figure 2. Samples of cement pastes (left) and mortar (right) after being broken in the compressive strength test

\subsection{Determination of Density}

The density test was done by directly relate to the strength of the product. The denser the sample the lower is the amount of pores is, leading to a higher resistance. For the 
determination of density the sample was weighed in an analytical scale and divided by the value obtained from the same volume [6].

\subsection{Determination of Leaching}

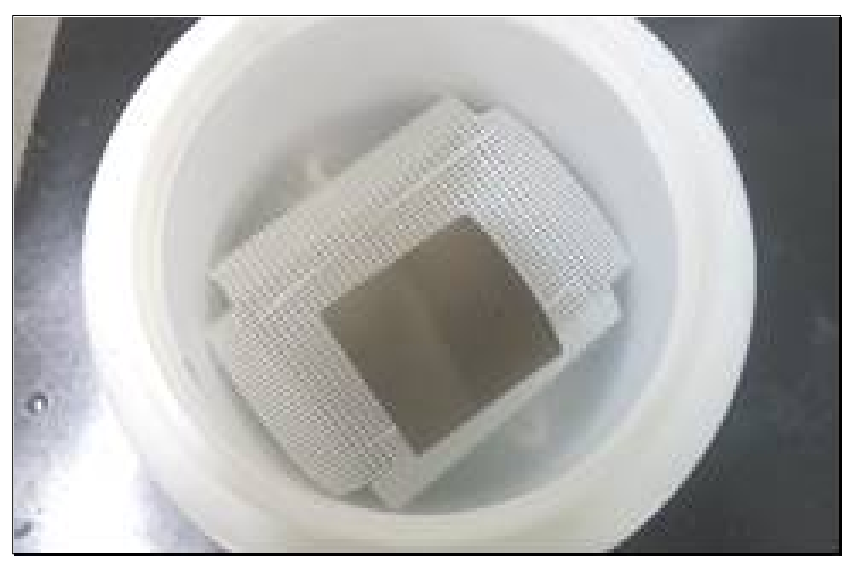

Figure 3. The leaching test

The leaching test was based on the leaching of ISO 6961 by subjecting the samples to a lixiviant solution, followed by quantitative analysis of the chemical element (cesium) leached $(30 \mathrm{mg} / \mathrm{sample})$. The samples after the leaching were sent to atomic absorption test to determine the amount of cesium leached (Figure 3). The leaching test has a duration of 1 year. [7].

The aim of this test is to assess the leaching, given that this is one of basic parameters for the radioactive waste product disposal according to CNEN-NN-6:09 standard.

\section{Procedure for Selecting the Best Model}

The results from the tests are presented in Table 1. The viscosity and setting time tests are performed only in the paste (formulation A) and it was not possible to do it in the test 3 because it was very viscous.

The standard CNEN-NE-6:09 establishes acceptance criteria for disposal of radioactive waste of low and intermediate level and specifies that the compressive strength at age of 28 days must be greater than or equal to 10 $\mathrm{MPa}$ [08]. All tests were within this specification.

Table 1. Results in pastes and mortars evaluated

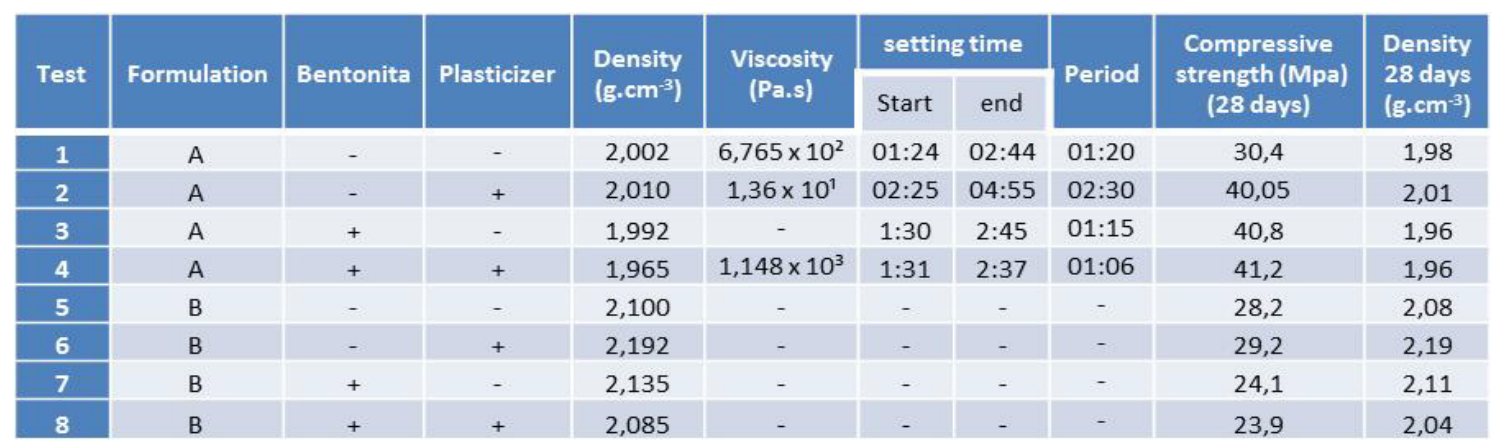

Formulation A (pastes: CPV-ARI and water); Formulation B (mortar - CPV ARI, water and sand)

without bentonita $(-)$; with bentonita $(+)$

without plasticizer $(-)$; with plasticizer $(+)$

It was observed that the use of Formulation A (paste) with bentonite and with plasticizer had higher values of compressive strength at age of 28 days and the lowest result was observed for formulation B (mortar) with plasticizer and with bentonite. The density values were higher for the mortar than the pastes, though the latter ones have higher values of compressive strength at age of 28 days. This can be explained because it has sand that provides increase in the porosity of the specimen, resulting in reduction of resistance.

For the realization of leaching test, we selected the two best results of the pastes and the mortar (tests 3, 4, 5 and 6). The aim of this test is to assess the leaching, given that this is one of basic parameters for the radioactive waste product disposal of CNEN-NN-6:09 standard [8].

The results are presented in Figure 3 and it is observed that each exchange showed a peak in the graph due to accumulation of cesium leached during the exchange period
[7].

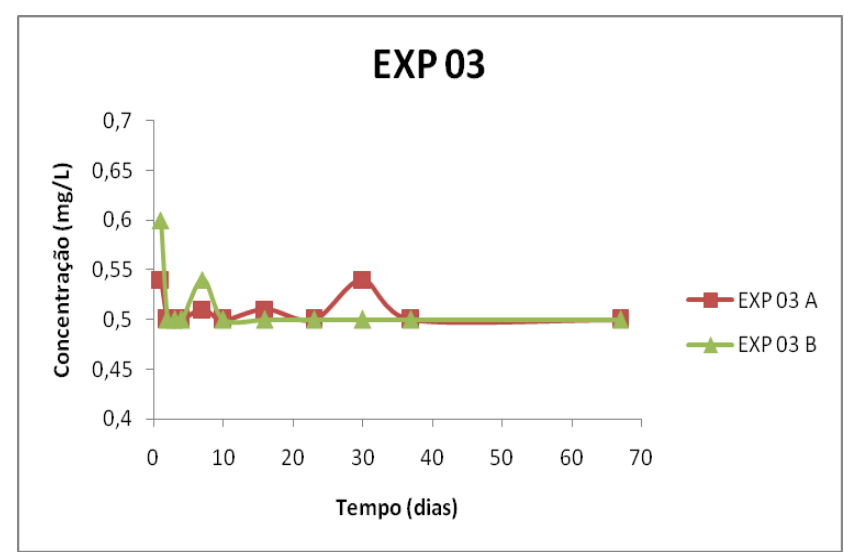



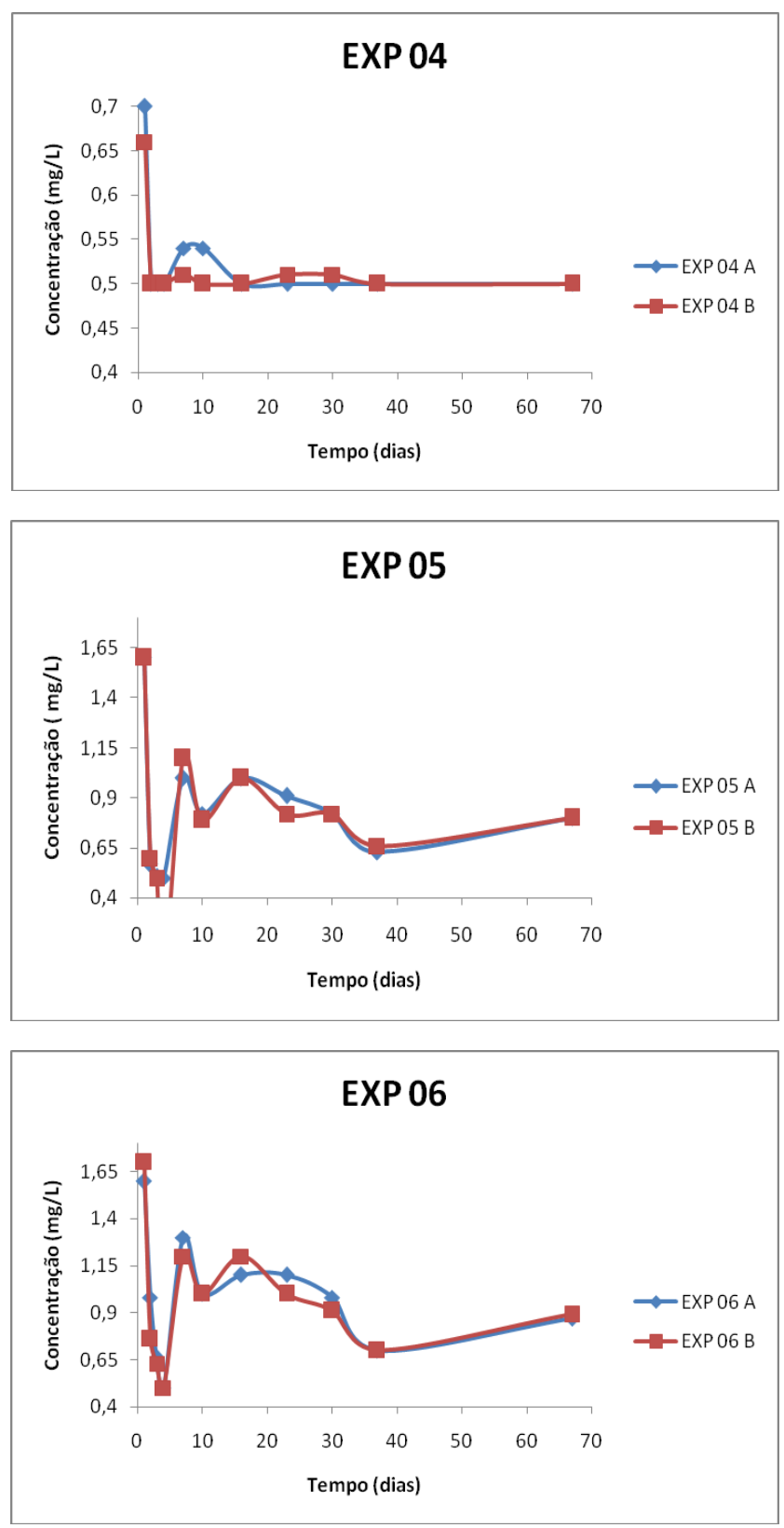

Figure 3. Leaching test results

\section{Conclusions}

For the evaluation of cement mortars and pastes the compressive strength at age of 28 days is considered a safety parameter relating to handling, transportation and storage of the cemented waste product. The regulation CNEN-NE-6.09 establishes that the compressive strength at age of 28 days must be greater than or equal to $10 \mathrm{MPa}$. Knowing that Portland CPV ARI cement provides compressive strength at age of 28 days above $10 \mathrm{MPa}$, bentonite and plasticizer was added in separate tests to confirm that this result would remain. All tests presented values were above this specification. It was observed that the use of Formulation A (paste) with bentonite and with plasticizer had the highest values of compressive strength at age of 28 days and the lowest values were observed for formulation B (mortar) with plasticizer and bentonite. The density values were higher for the mortar than the pastes, though the latter ones had higher values of compressive strength at age of 28 days. This can be explained because there is sand that provides an increase in the porosity of the specimen, resulting in the reduction of resistance For future work, the test of leaching in cement pastes and mortars will be finished and will be carried out a new test of leaching using bitumen encapsulated on cement pastes and mortars that showing better results in the leaching test.

\section{Acknowledgements}

This research project is supported by the following Brazilian institutions: Nuclear Technology Development Center (CDTN), Brazilian Nuclear Energy Commission (CNEN).

\section{REFERENCES}

[1] Eletronuclear, (2016). Panorama da energia nuclear no mundo. http://www.eletronuclear.gov.br

[2] Tello, C. C. O, (2008). Projeto de repositório para rejeitos radioativos de baixo e médio níveis de radiação. Relatório Técnico - Centro de Desenvolvimento da Tecnologia Nuclear - Belo Horizonte: CDTN / CNEN, Brazil.

[3] Ministério da Ciência e Tecnologia - MCT, (2007). Ciência, Tecnologia e Inovação para o Desenvolvimento Nacional. Plano de Ação. Brasília, Brasil, 406p.

[4] Brasil, (2001). Lei no 10.3085. Seleção de locais, a construção, o licenciamento, a operação, a físcalização, os custos, a indenização, a responsabilidade civil e as garantias referentes aos depósitos de rejeitos radioativos, e dá providências. Brasil.

[5] Tello, C. C. O., Cuccia, V, (2011). Experiência Internacional no uso da betuminização como processo de solidificação de rejeitos radioativos. Centro de Desenvolvimento da Tecnologia Nuclear (CDTN). Brasil.

[6] Tello, C. C. O, (2001). Efetividade das bentonitas na retenção de césio em produtos de rejeitos cimentados. Universidade Estadual de Campinas. Brasil.[8] INTERNATIONAL ATOMIC ENERGY AGENCY, 1992. Radioactive waste management: an IAEA source book. Vienna: IAEA, 276p.

[7] International Atomic Energy Agencym, (1992). Radioactive waste management: an IAEA source book. Vienna: IAEA, $276 \mathrm{p}$.

[8] Valcke, E. Gens, (2007). The Belgian approach towards the study of the compatibility of Eurobitum with the geological disposal environment. Belgian Nuclear Research Centre Mol: SCK•CEN, Belgian. 
[9] Associação Brasileira do Cimento Portland (ABCP MT-3), (1994). Manual de ensaios físicos de cimento. São Paulo: ABCP, Brasil

[10] International Organization for Standardization, (1982). ISO 6961: Long-term leach testing of solidified radioactive waste forms. Geneva: ISO.
[11] Comissão Nacional de Energia Nuclear - CNEN-NN-6.09, (2002). Critérios de aceitação para deposição de rejeitos radioativos de baixo e médio nível de radiação. Rio de Janeiro, Brasil.

[12] Deutsches Institut fur Normung, (2005). DIN 1995. Bituminous binder for road building requirements. Berlin: DIN. 